\title{
A Hierarchical Framework of Barriers to Green Supply Chain Management in the Construction Sector
}

\author{
Sreejith Balasubramanian ${ }^{1}$ \\ ${ }^{1}$ University of Wollongong Dubai, United Arab Emirates \\ Correspondence: Sreejith Balasubramanian, University of Wollongong Dubai, United Arab Emirates. E-mail: \\ sreejithsubramanian@uowdubai.ac.ae
}

Received: August 13, 2012 Accepted: September 7, 2012 Online Published: September 24, 2012

doi:10.5539/jsd.v5n10p15 URL: http://dx.doi.org/10.5539/jsd.v5n10p15

\begin{abstract}
The research paper presents a hierarchical sustainability framework for evaluating the barriers to the adoption of green supply chain management (GSCM) in the United Arab Emirates (UAE) construction sector. A total of 32 barriers to the adoption of GSCM are identified through extensive literature review and expert interviews with academics and industry professionals. The barriers are grouped on the basis of literature and expert opinion to form 12 criteria. Since the nature of the identified criteria is complex and interdependent; an Interpretive Structural Modeling (ISM) technique is applied to develop a structural model. Driving and dependence power analysis (DDPA) is used to classify and identify the critical barriers. The developed sustainability framework offers a strong and efficient evaluation technique in decision making for policy makers and stakeholders by means of identifying and prioritizing the critical barriers. The barriers identified are also classified as external and internal barriers to the organization and will help policy makers to focus on specific barriers which are important to the adoption of GSCM in the UAE construction sector. The framework has the potential to be applied to other countries across industries.
\end{abstract}

Keywords: sustainability, green supply chain management; interpretive structural modeling, driving and dependence power analysis, construction sector

\section{Introduction}

Construction sector accounts for $30-40 \%$ of the world's total carbon emission according to United Nations Environmental Program (2007). This percentage is higher for UAE, as construction sector contributes to $11.5 \%$ of the GDP in 2010 according to International Monetary Fund (2010). The total value of the construction projects of UAE in 2011 is estimated US\$319.1 billion according to MEED projects (2011). The rapid growth in the UAE construction sector as resulted in the increase of energy usage and related greenhouse gas (GHG) emissions. UAE tops the world on per capita carbon emission and was reported at 24.98 metric tons in 2008, according to the World Bank country report of UAE (2008). However in the UAE only $38 \%$ of companies recognize the importance of environmental issues in their supply chain strategy and $60 \%$ of the construction companies do not take into consideration green supply chain concerns while making strategic decisions (Rettab $\&$ Ben, 2008). These facts and figures are the basis for the research

GSCM is one of the best strategies for meeting the challenge to reduce carbon emission and enhance sustainability because of its potential to improve the environmental performance of any organizations. Although many past researchers have tried to measure the GSCM practices, implementation, performance and benefits, few have dedicated to develop a framework to understand and model the barriers to the adoption of GSCM in the first place. No previous research was carried in the region to develop a framework to model and assess the barriers of GSCM in the UAE construction sector and hence exist a knowledge gap which is critical to country like UAE where GSCM is still at the infancy stage. As such, federal and state governments are in need of a framework to encourage and regulate organizations to adopt a sustainable GSCM. Thus, lack of efficient framework to evaluate and model the barriers can lead to lack of green initiatives among construction industry stakeholders. Therefore following research questions are developed to overcome the knowledge gap,

1) Which are the critical barriers to the adoption of GSCM in the UAE construction sector?

2) What are the contextual relationships among the barriers? 
3) How to develop a framework which can easily display the complex interdependence of barriers?

4) How to classify the barriers based on their criticality and importance?

The research identified the barriers to the adoption of GSCM through extensive literature review, interviews and discussion with academics and industry experts. However most of the identified barriers are complex, interdependent and subjective in nature and cannot be easily assessed. Hence the concept of ISM technique (Warfield, 1974) is employed for modeling and analyzing the complex influence of one criterion on another and to create a hierarchical structural framework among the criteria. It meets the demands of complexity science and displays systematic structure (Warfield, 1999). Driving and Dependence Power Analysis (DDPA) is used for classifying the barriers with respect to driving and dependence power. The major objective of this paper can be summarized as follows:

1) To identify the critical barriers to the adoption of GSCM

2) To develop a hierarchical structural model of the barriers using ISM

3) To classify the barriers scientifically using DDPA

4) To develop a reliable sustainability framework that can be expanded to other countries across industries.

\section{Literature Review}

Studies in the field of GSCM are growing in terms of number of publications over the last decade; consequently organizations have shown growing interest in the concept of GSCM. Lamming and Hampson (1996), Beamon (1999), Hoffman (2007), Parry et al. (2007) have discussed the importance of GSCM. Zhu and Sarkis (2007), Srivastava (2007) have extensively reviewed green supply chain practices among organizations. However there are various barriers to the adoption of GSCM which can be internal or external to the organization.

\subsection{Review on Internal GSCM Barriers}

Hanna et al. (2000) discussed the need for aligning sustainable strategy with corporate strategy and having sustainable vision and mission. Hamel and Prahalad (1989), Ravi and Shankar (2005), Zhu and Sarkis (2007), Sarkis (2009), Digalwar and Metri (2004), Carter and Dresner (2001) have identified the importance of top management support and commitment in implementing successful GSCM whereas Drumwright (1994) reported the role of middle management. Efficient IT systems can enhance supply chain performance (Roger \& R. S, 1998; Alemayehu, 2008), Environmental monitoring system (EMS) is necessary for supporting GSCM across all stages (Ravi \& Shankar, 2005). AlKhidir and Zailani (2009), Yu (2007), Gant (1996) identified the importance of technology advancement for sustainable supply chain. Knowledge sharing within the organization and among stakeholders can improve the innovative adoption capability of the organization (Tsai \& Ghosal, 1999). Hence lack of information sharing can prevent innovative GSCM practices. Digalwar and Metri (2004) reported the need for better corporate culture in adopting innovative ideas and technology into the organization. Alkhidir and Zailani (2009) mentioned cost implications as barrier to GSCM. Organization wide cost reduction can act as a barrier for GSCM (Min \& Galle, 2001). Lack of knowledge and training (Cooper et al., 2000; Bowen et al., 2001) lack of experience (Yu \& Hui, 2008) are all important barriers for the adoption of GSCM.

\subsection{Review on External GSCM Barriers}

Banerjee et al. (2003) identified GSCM involves the cooperation and interaction among stakeholders. External stakeholders and environmental performance are the important factors affecting GSCM practices according to (Hall, 2000; Hall, 2006). Suppliers are important for the overall performance of the supply chain. Selection of green suppliers is important for the environmental performance of many organizations (Clarke, 1999). Supplier collaboration (Sharfman et al., 2007; Vachon \& Klassen, 2008; Verghese \& Lewis, 2007), lack of supplier commitment (Wycherley, 1999; Walker \& Preuss, 2008), supplier reluctance to change towards environmental sustainability are significant to the adoption of GSCM. Government influential policies (Carter \& Ellram, 1998; $\mathrm{Yu}, 2007$; Linton et al., 2007) are important to the adoption of GSCM.Customer desire for low prices (Orsato, 2006), customer demand (Sarkar \& Mohapatra, 2006; Doonan et al., 2005) are key for organizations to adopt sustainable solutions. Competitive pressures (Cooper et al., 2000) and market uncertainty (Yu \& Hui, 2008) also plays a vital role.

\subsection{Review on GSCM Modeling}

Interpretive Structural Modeling (Warfield, 1974) was adopted by many researchers to model GSCM. Luthra et al. (2011) developed ISM model to evaluate the barriers of GSCM in the automobile industry in India. Vimal et al. (2011) applied ISM technique to study the adoption of renewable energy in India. Ming and Yuan (2011) developed ISM based model for municipal solid waste management in Taipei metropolitan. Huang et al. (2005) 
proposed integrating ISM and analytical network process (ANP) to deal with problem of interdependence among subsystems. Mudgal et al. (2010) used ISM to model the enablers and barriers of GSCM in the Indian manufacturing industries. Chang (2010) used SEM to test the validity of interactive management (IM). Martilla and James (1977) developed driving and dependent power analysis (DDPA) to indicate the degree of dependence and driving power of criteria. The present research aims to develop a hierarchical sustainability framework for modeling the barriers to the adoption of GSCM in the construction industry using ISM and DDPA.

\section{ISM Modeling of Barriers}

ISM is an interactive learning process. The methodology used is interpretive, as the consensual judgment of the group decides whether or how the different barriers are related. ISM is characterized by decomposing the complex system into subsystems and then constructing the system into a multilevel hierarchical ISM (Sage, 1977). The final model portrays a well-defined structure of a complex problem.

The different steps involved in the ISM technique are explained in the following section:

\subsection{Identification of Barriers}

A total of 32 barriers (sub-criteria) to the adoption of GSCM are identified from the literature and interviews with experts from both academics and industry and grouped them together to form 12 criteria. All the criteria are later classified into external and internal criteria based on the literature. Table 1 illustrates the barriers to the adoption of GSCM. The identified criteria form the constituent elements of the ISM system. The set of criteria ' $\mathrm{C}$ ' is denoted as

$$
\mathrm{C}=\{\mathrm{c}(\mathrm{i}) \mid(\mathrm{i}=1,2 \ldots \mathrm{n})\}
$$

' $n$ ' is the number of criteria.

Table 1. Barriers to the Adoption of GSCM

\begin{tabular}{|c|c|c|c|}
\hline S.N & Criteria & Barriers(sub-criteria) & Classification \\
\hline \multirow[t]{2}{*}{1} & $\begin{array}{l}\text { Lack of sustainable GSCM } \\
\text { practices in organizations } \\
\text { vision and mission }\end{array}$ & 1.1 Lack of GSCM practices in organizations vision & Internal \\
\hline & & 1.2 Lack of GSCM practices in organizations mission & \\
\hline \multirow[t]{2}{*}{2} & $\begin{array}{l}\text { Lack of corporate } \\
\text { leadership and support }\end{array}$ & $\begin{array}{l}2.1 \text { Lack of top management support to the adoption } \\
\text { of GSCM }\end{array}$ & Internal \\
\hline & & $\begin{array}{l}2.2 \text { Lack of leadership and commitment from senior } \\
\text { and middle level managers }\end{array}$ & \\
\hline \multirow[t]{3}{*}{3} & $\begin{array}{l}\text { Lack of knowledge and } \\
\text { experience }\end{array}$ & $\begin{array}{l}\text { 3.1 Lack of knowledge in GSCM among the supply } \\
\text { chain stakeholders }\end{array}$ & Internal \\
\hline & & $\begin{array}{l}\text { 3.2 Lack of experience among the stakeholders in } \\
\text { executing GSCM }\end{array}$ & \\
\hline & & $\begin{array}{l}\text { 3.3 Feeling of 'too complex' to implement GSCM } \\
\text { among stakeholders }\end{array}$ & \\
\hline \multirow[t]{4}{*}{4} & Poor organizational culture & $\begin{array}{l}\text { 4.1 Organizations lack 'long term' vision and are short } \\
\text { term oriented }\end{array}$ & Internal \\
\hline & & $\begin{array}{l}\text { 4.2 Reluctance and resistance to change among } \\
\text { stakeholders }\end{array}$ & \\
\hline & & $\begin{array}{l}\text { 4.3 Lack of ethical standards and corporate social } \\
\text { responsibility }\end{array}$ & \\
\hline & & 4.4 High employee attrition rate & \\
\hline
\end{tabular}


Table 1. Barriers to the Adoption of GSCM (continued)

\begin{tabular}{|c|c|c|c|}
\hline S.N & Criteria & Barriers(sub-criteria) & Classification \\
\hline \multirow[t]{2}{*}{5} & Shortage of resources & $\begin{array}{l}\text { 5.1 Sufficient lack of green architects, consultants, } \\
\text { green developers, contractors in the region }\end{array}$ & External \\
\hline & & $\begin{array}{l}5.2 \text { Lack of skilled professionals in sustainability and } \\
\text { GSCM in the region }\end{array}$ & \\
\hline \multirow[t]{2}{*}{6} & $\begin{array}{l}\text { Lack of understanding } \\
\text { among supply chain } \\
\text { stakeholders }\end{array}$ & $\begin{array}{l}\text { 6.1 Lack of cooperation within the supply chain } \\
\text { stakeholders }\end{array}$ & Internal/External \\
\hline & & $\begin{array}{l}6.2 \text { Lack of communication and information sharing } \\
\text { among supply chain stakeholders }\end{array}$ & \\
\hline \multirow[t]{3}{*}{7} & $\begin{array}{l}\text { Lack of technology } \\
\text { infrastructure }\end{array}$ & $\begin{array}{l}\text { 7.1 Lack of IT infrastructure systems like } \\
\text { environmental monitoring system(EMS) in the } \\
\text { organization }\end{array}$ & Internal \\
\hline & & $\begin{array}{l}7.2 \text { Lack of innovative technology in manufacturing } \\
\text { and construction }\end{array}$ & \\
\hline & & $\begin{array}{l}7.3 \text { Lack of technology for waste management and } \\
\text { recycling }\end{array}$ & \\
\hline \multirow[t]{4}{*}{8} & Lack of green initiatives & 8.1 Lack of training in GSCM & Internal \\
\hline & & $\begin{array}{l}8.2 \text { Lack of internal sustainability audits within the } \\
\text { organization }\end{array}$ & \\
\hline & & $\begin{array}{l}\text { 8.3 Lack of external sustainability audits of suppliers } \\
\text { and contractors }\end{array}$ & \\
\hline & & $\begin{array}{l}\text { 8.4 Lack of sustainability certifications like IS0 } \\
14001\end{array}$ & \\
\hline \multirow[t]{2}{*}{9} & $\begin{array}{l}\text { Perceived lack of } \\
\text { government support }\end{array}$ & $\begin{array}{l}\text { 9.1 Lack of government incentives and best practices } \\
\text { awards for adopting GSCM }\end{array}$ & External \\
\hline & & $\begin{array}{l}\text { 9.2 Lack of preferential treatment and long term } \\
\text { contracts for adopting GSCM from government }\end{array}$ & \\
\hline \multirow[t]{3}{*}{10} & Financial implications & 10.1 High initial investment in implementing GSCM & Internal/External \\
\hline & & $\begin{array}{l}\text { 10.2 Slow return on Investments(ROI) after } \\
\text { implementing GSCM }\end{array}$ & \\
\hline & & 10.3 Low profit margins & \\
\hline \multirow[t]{3}{*}{11} & $\begin{array}{l}\text { Competition and } \\
\text { uncertainty }\end{array}$ & 11.1 High competition in the construction sector & External \\
\hline & & $\begin{array}{l}\text { 11.2 Market uncertainty due to project delay, project } \\
\text { on hold and cancellation }\end{array}$ & \\
\hline & & 11.3 International crisis and economic down turn & \\
\hline \multirow[t]{2}{*}{12} & $\begin{array}{l}\text { Lack of demand and public } \\
\text { awareness }\end{array}$ & $\begin{array}{l}\text { 12.1 Lack of public or customer awareness on } \\
\text { sustainability issue }\end{array}$ & External \\
\hline & & $\begin{array}{l}\text { 12.2 Lack of customer demands for sustainable } \\
\text { projects }\end{array}$ & \\
\hline
\end{tabular}

\subsection{Development of Structural Self Interaction Matrix (SSIM)}

After identifying the 12 criteria, a 3 hour workshop was conducted which comprises construction industry practioners and academics from related field to identify the nature of the contextual relationships among the 
criteria. The profile of the 11 participants in the workshop where senior to middle level managers, consultants, project and procurement managers in the construction industry, associate professors and researchers in the field of construction and supply chain. Consensus was reached on the direction of the relation between any combination of criteria $i$ and $j$. The number of pair wise combination questions addressed for developing SSIM is $\left(N^{*}(N-1) / 2\right)$, in this case is 66 . Four symbols are used to denote the direction of the relationship between the criteria $i$ and $j$.

$V$-criteria $i$ lead to criteria $j$

$A$-criteria $j$ lead to criteria $i$

$X$-criteria $i$ and $j$ will lead to each other

$O$-criteria $i$ and $j$ are unrelated

The developed SSIM matrix is given in Table 2.

Table 2. SSIM

\begin{tabular}{cllllllllllll}
\hline S.N & Barriers to adoption of GSCM & 12 & 11 & 10 & 9 & 8 & 7 & 6 & 5 & 4 & 3 & 2 \\
\hline 1 & $\begin{array}{l}\text { Lack of sustainable GCM practices in the } \\
\text { organizations vision and mission }\end{array}$ & A & A & A & A & V & V & X & A & V & V & A \\
2 & Lack of Corporate leadership and support & A & A & A & A & V & V & V & A & V & A & X \\
3 & Lack of knowledge and experience & O & O & V & O & V & V & V & A & V & X & \\
4 & Lack of organizational culture & O & O & V & O & V & V & V & A & X & & \\
5 & Shortage of resources & O & O & V & O & V & V & V & X & & \\
6 & Lack of understanding among stakeholders & A & A & A & A & V & A & X & & & \\
7 & Lack of technology infrastructure & O & A & A & O & V & X & & & & \\
8 & Lack of green initiatives & A & A & A & A & X & & & & & \\
9 & Perceived lack of government benefits & O & O & V & X & & & & & \\
10 & Financial implications & O & A & X & & & & & & & \\
11 & Competition and uncertainty & Lack of demand and public awareness & X & & & & & & & & &
\end{tabular}

SSIM based on the contextual relationship among the criteria.

\subsection{Development of Reachability Matrix (RM)}

The SSIM is then transformed into a binary matrix called initial RM by substituting $V, A, X, O$ by 1 or 0 by applying the following rules:

If the element $(i, j)$ in the SSIM is $V$, then $(i, j)$ element in the RM becomes 1 and $(j, i)$ element becomes 0 .

If the element $(i, j)$ in the SSIM is $A$, then $(i, j)$ element in the RM becomes 0 and $(j, i)$ element becomes 1 .

If the element $(i, j)$ in the SSIM is $X$, then $(i, j)$ element in the RM becomes 1 and $(j, i)$ element becomes 1 .

If the element $(i, j)$ in the SSIM is $O$, then $(i, j)$ element in the RM becomes 0 and $(j, i)$ element becomes 0 .

The initial RM for the barriers to the adoption of GSCM is given in Table 3.The final RM is obtained by applying transitivity, an assumption made in ISM which states if criteria $\mathrm{a}$ is related to $\mathrm{b}$ and $\mathrm{b}$ is related to then a is related $\mathrm{c}$ is given in Table 4. 
Table 3. Initial RM

\begin{tabular}{llllllllllllll}
\hline S. N & Barriers to adoption of GSCM & 1 & 2 & 3 & 4 & 5 & 6 & 7 & 8 & 9 & 10 & 11 & 12 \\
\hline 1 & $\begin{array}{l}\text { Lack of sustainable practices in the } \\
\text { organizations vision and mission }\end{array}$ & 1 & 0 & 1 & 1 & 0 & 1 & 1 & 1 & 0 & 0 & 0 & 0 \\
2 & Lack of Corporate leadership and support & 1 & 1 & 0 & 1 & 0 & 1 & 1 & 1 & 0 & 0 & 0 & 0 \\
3 & Lack of knowledge and experience & 0 & 1 & 1 & 1 & 0 & 1 & 1 & 1 & 0 & 1 & 0 & 0 \\
4 & Lack of organizational culture & 0 & 0 & 0 & 1 & 0 & 1 & 1 & 1 & 0 & 1 & 0 & 0 \\
5 & Shortage of resources & 1 & 1 & 1 & 1 & 1 & 1 & 1 & 1 & 0 & 1 & 0 & 0 \\
6 & Lack of understanding among & & & & & & & & & & & & \\
7 & stakeholders & Lack of technology infrastructure & 0 & 0 & 0 & 0 & 0 & 1 & 1 & 1 & 0 & 0 & 0 \\
8 & Lack of green initiatives & 0 & 0 & 0 & 0 & 0 & 0 & 0 & 1 & 0 & 0 & 0 & 0 \\
9 & Perceived lack of government benefits & 1 & 1 & 0 & 0 & 0 & 1 & 0 & 1 & 1 & 1 & 0 & 0 \\
10 & Financial implications & 1 & 1 & 0 & 0 & 0 & 1 & 1 & 1 & 0 & 1 & 0 & 0 \\
11 & Competition and uncertainty & 1 & 1 & 0 & 0 & 0 & 1 & 1 & 1 & 0 & 1 & 1 & 0 \\
12 & Lack of demand and public awareness & 1 & 1 & 0 & 0 & 0 & 1 & 0 & 1 & 0 & 0 & 0 & 1 \\
\hline
\end{tabular}

Table 4. Final RM

\begin{tabular}{|c|c|c|c|c|c|c|c|c|c|c|c|c|c|c|}
\hline S. N & Barriers to adoption of GSCM & 1 & 2 & 3 & 4 & 5 & 6 & 7 & 8 & 9 & 10 & 11 & 12 & $\begin{array}{l}\text { Driving } \\
\text { Power }\end{array}$ \\
\hline 1 & $\begin{array}{l}\text { Lack of sustainable practices in } \\
\text { the organizations vision and } \\
\text { mission }\end{array}$ & 1 & 0 & 1 & 1 & 0 & 1 & 1 & 1 & 0 & $1^{*}$ & 0 & 0 & 6 \\
\hline 2 & $\begin{array}{l}\text { Lack of Corporate leadership and } \\
\text { support }\end{array}$ & 1 & 1 & $1^{*}$ & 1 & 0 & 1 & 1 & 1 & 0 & $1^{*}$ & 0 & 0 & 6 \\
\hline 3 & $\begin{array}{l}\text { Lack of knowledge and } \\
\text { experience }\end{array}$ & $1^{*}$ & 1 & 1 & 1 & 0 & 1 & 1 & 1 & 0 & 1 & 0 & 0 & 7 \\
\hline 4 & Lack of organizational culture & $1^{*}$ & $1^{*}$ & 0 & 1 & 0 & 1 & 1 & 1 & 0 & 1 & 0 & 0 & 5 \\
\hline 5 & Shortage of resources & 1 & 1 & 1 & 1 & 1 & 1 & 1 & 1 & 0 & 1 & 0 & 0 & 9 \\
\hline 6 & $\begin{array}{l}\text { Lack of understanding among } \\
\text { stakeholders }\end{array}$ & 1 & 0 & $1^{*}$ & $1^{*}$ & 0 & 1 & $1^{*}$ & $1^{*}$ & 0 & 0 & 0 & 0 & 2 \\
\hline 7 & Lack of technology infrastructure & $1 *$ & 0 & 0 & 0 & 0 & 1 & 1 & 1 & 0 & 0 & 0 & 0 & 3 \\
\hline 8 & Lack of green initiatives & 0 & 0 & 0 & 0 & 0 & 0 & 0 & 1 & 0 & 0 & 0 & 0 & 1 \\
\hline 9 & $\begin{array}{l}\text { Perceived lack of government } \\
\text { benefits }\end{array}$ & 1 & 1 & $1^{*}$ & $1 *$ & 0 & 1 & $1^{*}$ & 1 & 1 & 1 & 0 & 0 & 6 \\
\hline 10 & Financial implications & 1 & 1 & $1^{*}$ & $1 *$ & 0 & 1 & 1 & 1 & 0 & 1 & 0 & 0 & 6 \\
\hline 11 & Competition and uncertainty & 1 & 1 & $1^{*}$ & $1^{*}$ & 0 & 1 & 1 & 1 & 0 & 1 & 1 & 0 & 7 \\
\hline 12 & $\begin{array}{l}\text { Lack of demand and public } \\
\text { awareness }\end{array}$ & 1 & 1 & $1^{*}$ & $1^{*}$ & 0 & 1 & $1^{*}$ & 1 & 0 & 0 & 0 & 1 & 5 \\
\hline & Dependence Power & 8 & 7 & 3 & 5 & 1 & 11 & 8 & 11 & 1 & 6 & 1 & 1 & $84 / 84$ \\
\hline
\end{tabular}

Derived final RM by applying transitivity. The transitivity links are denoted by *.

\subsection{Level Partitioning}

The Reachability set (RS) and the Antecedent Set (AS) (Warfield, 1974) is extracted from the final RM. The RS consist of the criterion itself and the others which it may help achieve whereas the AS consists of the criterion 
itself and the other criteria which may help achieve it. Intersection of RS and AS is obtained for all the criteria. The criteria for which the RS and intersection set are the same is ranked $1^{\text {st }}$ and placed at the top level in the ISM hierarchical structure. Once the top level criteria are identified, the criteria are removed and the iteration is continued to find the level of each criterion. In this case, the level partitioning process for the 12 criteria was completed in 6 iterations. Iteration 1 and the final level partitions are given in Table 5 and Table 6 respectively.

Table 5. First Iteration

\begin{tabular}{|c|c|c|c|c|c|}
\hline S. N & Barriers to adoption of GSCM & $\mathrm{RS}$ & AS & Intersection & Level \\
\hline 1 & $\begin{array}{l}\text { Lack of sustainable practices in the } \\
\text { organizations vision and mission }\end{array}$ & $1,3,4,6,7,8,10$ & $\begin{array}{l}1,2,3,4,5,6,7,9,10 \\
11,12\end{array}$ & $\begin{array}{l}1,3,4,6,7 \\
10\end{array}$ & \\
\hline 2 & Lack of Corporate leadership and support & $\begin{array}{l}1,2,3,4,6,7,8 \\
10\end{array}$ & $2,3,4,5,9,10,11,12$ & $2,3,4,10$ & \\
\hline 3 & Lack of knowledge and experience & $\begin{array}{l}1,2,3,4,6,7,8 \\
10\end{array}$ & $1,2,3,5,6,9,10,11,12$ & $1,2,3,6,10$ & \\
\hline 4 & Lack of organizational culture & $1,2,4,6,7,8,10$ & $\begin{array}{l}1,2,3,4,5,6,9,10,11, \\
12\end{array}$ & $1,2,4,6,10$ & \\
\hline 5 & Shortage of resources & $\begin{array}{l}1,2,3,4,5,6,7,8 \\
10\end{array}$ & 5 & 5 & \\
\hline 6 & $\begin{array}{l}\text { Lack of understanding among } \\
\text { stakeholders }\end{array}$ & $1,3,4,6,7,8$ & $\begin{array}{l}1,2,3,4,5,6,7,9,10 \\
11,12\end{array}$ & $1,3,4,6,7$ & \\
\hline 7 & Lack of technology infrastructure & $1,6,7,8$ & $\begin{array}{l}1,2,3,4,5,6,7,9,10 \\
11,12\end{array}$ & $1,6,7$ & \\
\hline 8 & Lack of green initiatives & 8 & $\begin{array}{l}1,2,3,4,5,6,7,8,9,10 \\
11,12\end{array}$ & 8 & $1 \mathrm{st}$ \\
\hline 9 & Perceived lack of government benefits & $\begin{array}{l}1,2,3,4,6,7,8,9 \\
10\end{array}$ & 9 & 9 & \\
\hline 10 & Financial implications & $\begin{array}{l}1,2,3,4,6,7,8 \\
10\end{array}$ & $1,2,3,4,5,9,10,11$ & $1,2,3,4,10$ & \\
\hline 11 & Competition and uncertainty & $\begin{array}{l}1,2,3,4,6,7,8 \\
10,11\end{array}$ & 11 & 11 & \\
\hline 12 & Lack of demand and public awareness & $\begin{array}{l}1,2,3,4,6,7,8, \\
12\end{array}$ & 12 & 12 & \\
\hline
\end{tabular}

Table 6. Level Partitioning of Criteria

\begin{tabular}{clc}
\hline S. N & Barriers to adoption of GSCM & Level \\
\hline 1 & Lack of sustainable practices in the organizations vision and mission & II \\
2 & Lack of Corporate leadership and support & IV \\
3 & Lack of knowledge and experience & V \\
4 & Lack of organizational culture & IV \\
5 & Shortage of resources & VI \\
6 & Lack of understanding among stakeholders & II \\
7 & Lack of technology infrastructure & III \\
8 & Lack of green initiatives & I \\
9 & Perceived lack of government benefits & V \\
10 & Financial implications & IV \\
11 & Competition and uncertainty & V \\
12 & Lack of demand and public awareness & V \\
\hline
\end{tabular}

The final level partitioning of criteria obtained after the $6^{\text {th }}$ iteration. 


\subsection{Development of Diagraph}

Directed graph (Diagraph) is generated from the final RM by the vertices and edges (Jharkaria \& Shankar, 2005). After removing the transitivity, a final digraph is developed. The relationship between the criteria is represented by an arrow. In the digraph the top level criteria obtained from level partitioning is positioned at the top and subsequent lower levels are placed till the bottom level is placed at the lowest position in the diagraph. The final diagraph developed after removing the transitivity links is given in Figure 1.

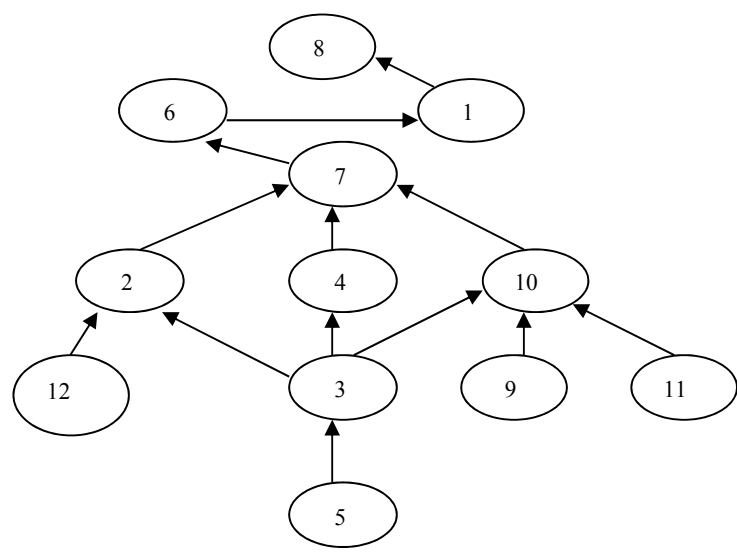

Figure 1. Diagraph of the criteria

\section{DDPA and Classification of Criteria}

Driving and dependence power of each criteria are calculated from the final RM. Driving power of each criteria is the total number of criteria (including itself), which it may help achieve by adding up the number of ones in the columns. Dependence power of each criteria is the total number of criteria (including itself), which may help achieve it. Table 4 provides the driving and dependence power of all the 12 criteria

\subsection{Classification of Criteria into Clusters}

A graph between dependence power and driving power of the criteria is presented in Figure 2.

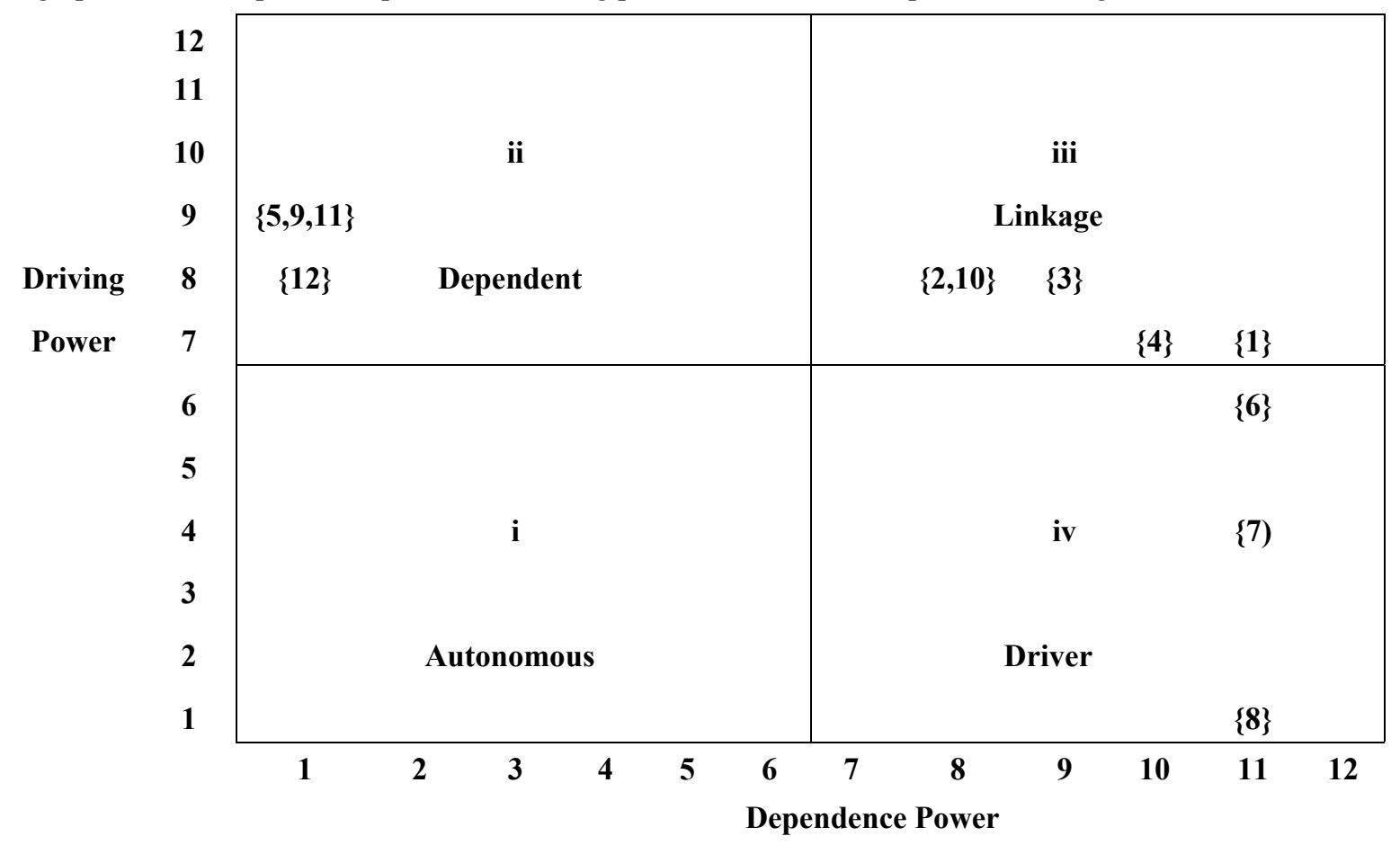

Figure 2. Classification of criteria by cluster for the adoption of GSCM 
All criteria are classified based on DDPA analysis into four clusters; autonomous, dependent, linkage and independent criteria (Mandal \& Deshmukh, 1994). In our research no criteria was classified as autonomous (first cluster). The criteria lack of understanding among stakeholders, lack of technology infrastructure, lack of green initiatives $(6,7,8)$ are classified as dependent criteria (second cluster) towards GSCM in the construction industry. The linkage criteria (third cluster) are; lack of top management support and leadership, financial implications, lack of knowledge and experience, poor organizational culture, lack of GSCM practices in organization's vision and mission $(1,2,3,4,10)$. Similarly shortage of resources, perceived lack of government support, competition and uncertainty and lack of public awareness and demand $(5,9,11,12)$ are classified has driving criteria.

\subsection{Further Classification Using Improvised DDPA}

In order to get further insights, criteria are further classified into external barriers, internal barriers and barriers which are influenced by both internal and external criteria based on the literature and hence identified 6 internal, 4 external and 2 internal/external barriers. Improvised DDPA is conducted to understand the dominant nature of the criteria, the results along with the summary of all the classification discussed in the paper is presented in Table 7.

Table 7. Summary of classifications

\begin{tabular}{|c|c|c|c|c|c|c|c|c|}
\hline S.N & Barrier criteria & Classification & Quadrant & $\begin{array}{l}\text { Driving } \\
\text { Power }\end{array}$ & $\begin{array}{l}\text { Dependence } \\
\text { power }\end{array}$ & $\begin{array}{c}\text { Net } \\
\text { Value }\end{array}$ & $\begin{array}{l}\text { Dominant } \\
\text { Nature }\end{array}$ & $\begin{array}{l}\text { Rank } \\
\text { level }\end{array}$ \\
\hline 1 & $\begin{array}{l}\text { Lack of sustainable } \\
\text { GSCM practices in } \\
\text { organizations vision and } \\
\text { mission }\end{array}$ & Internal & Linkage & 7 & 11 & -4 & Dependent & II \\
\hline 2 & $\begin{array}{l}\text { Lack of Corporate } \\
\text { leadership and support }\end{array}$ & Internal & Linkage & 8 & 8 & 0 & Equal & IV \\
\hline 3 & $\begin{array}{l}\text { Lack of knowledge and } \\
\text { experience }\end{array}$ & Internal & Linkage & 8 & 9 & -1 & Dependent & $\mathrm{V}$ \\
\hline 4 & $\begin{array}{l}\text { Lack of organizational } \\
\text { culture }\end{array}$ & Internal & Linkage & 7 & 10 & -3 & Dependent & IV \\
\hline 5 & Shortage of resources & External & Driver & 9 & 1 & 8 & Driver & Vl \\
\hline 6 & $\begin{array}{l}\text { Lack of understanding } \\
\text { among stakeholders }\end{array}$ & $\begin{array}{l}\text { Internal/ } \\
\text { External }\end{array}$ & Linkage & 6 & 11 & -5 & Dependent & II \\
\hline 7 & $\begin{array}{l}\text { Lack of technology } \\
\text { infrastructure }\end{array}$ & Internal & Dependent & 4 & 11 & -7 & Dependent & III \\
\hline 8 & Lack of green initiatives & Internal & Dependent & 1 & 12 & -11 & Dependent & I \\
\hline 9 & $\begin{array}{l}\text { Perceived lack of } \\
\text { government benefits }\end{array}$ & External & Driver & 9 & 1 & 8 & Driver & $\mathrm{V}$ \\
\hline 10 & Financial implications & $\begin{array}{l}\text { Internal/ } \\
\text { External }\end{array}$ & Linkage & 8 & 8 & 0 & Equal & IV \\
\hline 11 & $\begin{array}{l}\text { Competition and } \\
\text { uncertainty }\end{array}$ & External & Driver & 9 & 1 & 8 & Driver & V \\
\hline 12 & $\begin{array}{l}\text { Lack of demand and } \\
\text { public awareness }\end{array}$ & External & Driver & 8 & 1 & 7 & Driver & V \\
\hline
\end{tabular}

Net Value (NV) = Driving power-Dependence Power.

(+) NV indicates driving nature of the barrier and (-) NV indicates the dependent nature of the barrier and 0 indicates equal driving and dependent nature of the barrier. The results shows all the external barriers have $(+)$ $\mathrm{NV}$ and internal, internal/external barriers have either (-) or $0 \mathrm{NV}$. All the external barriers $(5,9,11$, and 12) act as drivers for the non-adoption of GSCM in the construction industry and all other barriers are dependent on 
these external barriers.

\section{The Final ISM Model}

The digraph presented in Figure 1 is converted into the final ISM model by replacing the criteria nodes with statements. The ISM based model is reviewed for conceptual inconsistency and necessary modifications are made and the final model is presented in Figure 3.

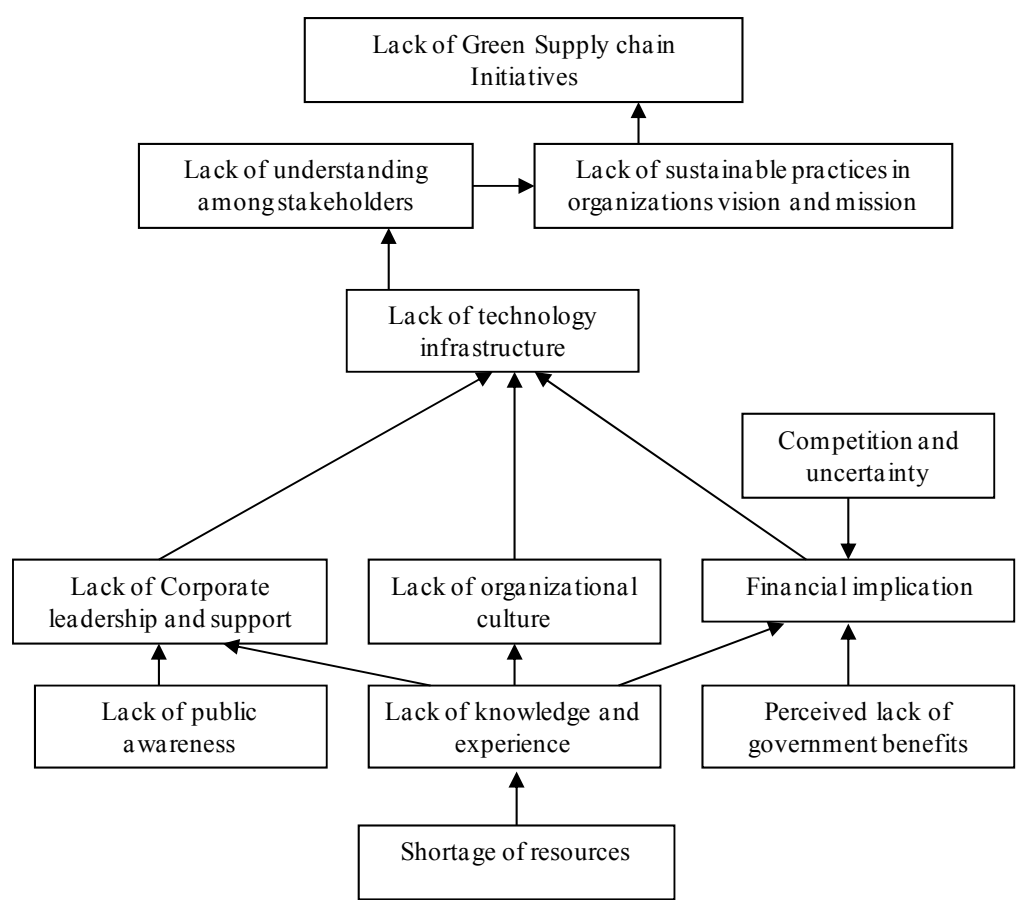

Figure 3. Final ISM model

\section{Discussion and Conclusion}

The paper presented a hierarchical framework to evaluate the barriers to the adoption of GSCM in the UAE construction sector. The research highlights can be summarized as follows.

- An extensive identification of 32 barriers among economic, environmental, technological, social and cultural aspects to the adoption of GSCM in the UAE construction sector.

- A scientific hierarchical modeling of barriers and their inter-relationship.

- A Comprehensive classification of barriers to understand their criticality for decision making.

- Potential of the framework to be extended to other GCC countries such as Oman and Qatar having similar GDP, Human development index(HDI) and e-readiness index

However there are limitations to the study due to the inherent subjectivity of the ISM approach. The opinions of experts may be biased or do not reflect the real world setting. The results are not numerically validated. A quantitative approach such as Structural Equation Modeling (SEM) can be used to test the validity of the developed ISM model and numerically measure the strength of association among barriers. Scope of future work involves integrating ISM model with SEM and country/industry wise adaptation of the framework.

Through the research, the paper identified factors external to the organization such as lack of skilled sustainability professionals, lack of green suppliers \& developers, lack of government support, lack of public awareness \& demand and market uncertainty are the critical barriers to the adoption of GSCM in the UAE construction sector. The internal barriers are dependent to the external barriers. The onus is on state and federal governments in UAE to formulate GSCM strategy plan to overcome the external barriers. The strategy plan should emphasis on empowering people to make sustainable choices and encouraging them to participate actively in the conceptualization, planning and execution of GSCM policies. Government should develop policies to attract skilled professionals, suppliers and developers to the region. 


\section{Acknowledgements}

Particular thanks to my research supervisor Dr.Vinaya Shukla and my mentor Dr.Balan Sundarakani and all the participants from academics and industry who participated in the workshop and for their valuable insights. Also grateful to companies who have shared their views and comments.

\section{References}

Alemayehu, M. (2008). GITAM: A model for the adoption of green IT. 19th Australasian Conference on Information Systems, 3-5 December, Christchurch.

AlKhidir, T., \& Zailani, S. (2009). Going green in supply chain towards environmental sustainability. Global Journal of Environmental Research, 3(3), 246-251.

Banerjee, S. B., Lyer, E. S., \& Kashyap, R. K. (2003). Corporate environmentalism: Antecedents and influence of industry type. Journal of Marketing, 67(2), 106-122. http://dx.doi.org/10.1509/jmkg.67.2.106.18604

Beamon, B. M. (1999). Designing the green Supply Chain. Logistics Information Management, 12(4), 332-342. http://dx.doi.org/10.1108/09576059910284159

Bowen, F. E., Cousins, P. D., Lamming, R. C., \& Faruk, A. C. (2001). Horses for courses: explaining the gap between the theory and practice of green supply. Greener Management International, 35, 41-60.

Carter, C. R., \& Dresner, M. (2001). Purchasing's Role in Environmental Management: Cross-Functional Development of Grounded Theory. Journal of Supply Chain Management, 37(2), 12-27, June 2001. http://dx.doi.org/ 10.1111/j.1745-493X.2001.tb00102.x

Carter, C. R., \& Ellram, L. M. (1998). Reverse logistics: a review of the literature and framework for future investigation. International Journal of Purchasing and Materials Management, 34(4), 28-38.

Chang, N. (2010). Using Structural Equation Modeling to Test the Validity of Interactive Management.Western Political Science Association 2010 Annual Meeting Paper. Retrieved from http://ssrn.com/abstract $=1580590$

Clark, D. (1999). What drives companies to seek ISO 14000.Pollution Engineering, 14-15

Cooper, R., Frank, G., \& Kemp, R. (2000). A multinationalcomparison of key ethical issues helps and challenges in the purchasing and supply management profession: the key implications for business and the professions. Journal of Business Ethics, 23(1), 83-100. http://dx.doi.org/10.1023/A:1006279112858

Digalwar, K., \& Metri, B. (2005). Performance measurement framework for World-class manufacturing. The International Journal of Applied Management and Technology, 3(2), 83-101.

Doonan, J., Lanoie, P., \& Laplante, B. (2005). Analysis determinants of environmental performance in the Canadian pulp and paper industry: an assessment from inside the industry. Ecol. Econ, 55, 73-84. http://dx.doi.org/10.1016/j.ecolecon.2004.10.017

Drumwright, M. (1994). Socially Responsible Organisational Buying: Environmental Concern as a Non-economic Buying Criterion. Journal of Marketing, 58.

Gant, R. M. (1996). Prospering in dynamically-competitive environments: Organizational capability as knowledge integration. Organizational Science, 7(4), 375-387. http://dx.doi.org/10.1287/orsc.7.4.375

Hall, J. (2000). Environmental supply chain dynamics. Journal of Cleaner Production, 8(6), 455-71. http://dx.doi.org/10.1016/S0959-6526(00)00013-5

Hall, J. (2006). Environmental supply chain innovation. In J. Sarkis (Ed.). Greening the Supply Chain, Springer, London. http://dx.doi.org/10.1007/1-84628-299-3_13

Hamel, G., \& Prahalad, C. K. (1989). Strategic intent. Harvard Business Review, 67, 63-76.

Hanna, M. D., Newman, W. R., \& Johnson, P. (2000). Linking operational and environmental improvement through employee involvement. International Journal of Operations \& Production Management, 20(2), 148-65. http://dx.doi.org/10.1108/01443570010304233

Helen, W., \& Neil, J. (2012). Sustainable supply chain management across the UK private sector. Supply Chain Management: An International Journal, 17(1), 15-28. http://dx.doi.org/10.1108/13598541211212177

Hoffman, W. (2007). Who's Carbon-Free? Wal-Mart takes on supply chains of products as expansive carbon measuring plan eyes distribution. Traffic World, Oct. 22 (pp.1-2). 
Huang, S. H., Sunil, K, S., \& Harshal, K. (2005). Computer-assisted supply chain configuration based on supply chain operations reference (SCOR) model. Computers and Industrial Engineering, 48(2), 377-394. http://dx.doi.org/10.1016/j.cie.2005.01.001

Jharkharia, S., \& Shankar, R. (2005). IT enablement of supply chains: understanding the barriers. Journal of Enterprise Information Management, 18(1), 11-27. http://dx.doi.org/10.1108/17410390610658432

James, E. (2010). The Meed View of the GCC Construction market. Retrieved from http://www.slideshare.net/meeddubai1/the-meed-view-of-the-gcc-construction-market-2010

Lambert, D. M., \& M. C. Cooper. (2000). Issues in Supply Chain Management. Industrial Marketing Management, 29(1), 65-83. http://dx.doi.org/10.1016/S0019-8501(99)00113-3

Lamming, R. C., \& Hampson, J. (1996). The Environment as a Supply Chain Management Issue. British Journal of Management, 7, S46 - 62.

Linton, J. D., Klassen, R., \& Jayaraman, V. (2007). Sustainable supply chains: an introduction. Journal of Operations Management, 25(6), 1075-82. http://dx.doi.org/10.1016/j.jom.2007.01.012

Luthra, S., Kumar, V., Kumar, S., \& Haleem, A. (2011). Barriers to implement green supply chain management in automobile industry using interpretive structural modeling technique: An Indian perspective. Journal of $\begin{array}{llll}\text { Industrial Engineering } & \text { and 231-257. }\end{array}$ http://dx.doi.org/10.3926/jiem.2011.v4n2.p231-257

Mandal, A., \& Deshmukh, S. G. (1994). Vendor selection using interpretive structural modelling (ISM). International Journal of Operations and Production Management, 14(6), 52-59. http://dx.doi.org/10.1108/01443579410062086

Martilla, J. A., \& James, J. C. (1977). Importance- Performance Analysis. Journal of marketing, 41, 77-79.

Min, H., \& Galle, W. P. (2001). Green purchasing practices of US firms. International Journal of Operations \& Production Management, 2l(9). 1222 - 1238. http://dx.doi.org/10.1108/EUM0000000005923

Ming, L. T., \& Yuan, H. L. (2011). Modeling a hierarchical structure of municipal solid waste management using interpretive structural modelling. Wseas Transactions on Environment and Development, 11(7), Nov 2011.

Mudgal, R. K., Shankar, R., Talib, P., \& Raj, T. (2010). Greening the supply chain practices: an Indian perspective of enablers relationships. International Journal of Advanced Operations Management, 1(2-3), 151-176.

Orsato, R. (2006). Competitive environmental strategies: when does it pay to be green? California Management Review, 48(2), 127-43.

Parry, P., Martha, J., \& Grenon, G. (2007). The Energy Efficient Supply Chain. Strategy+Business, Booz Allen Hamilton (Issue 47, pp.1-10).

Ravi, V., \& Shankar, R. (2005). Analysis of interactions among the barriers of reverse logistics. International Journal of Technological Forecasting and Social Change, 72(8), 1011-1029.

Rettab, B., \& Ben, B. A. (2008). Green Supply Chain in Dubai. Dubai Chamber Center for Responsible Business, Dubai, UAE. Retrieved from http://www.dubaichamber.com/wp-content/uploads/2009/07/GREEN-SUPPLY-CHAIN-IN-DUBAI.pdf

Rogers, D. S., \& R. S. (1998). Tibben- lembke, going backwards: Reverse logistics trends and practices. Reverse Logistics Executive Council, Pittsburgh, PA.

Sage, A. (1977). Interpretive Structural Modeling: Methodology for large scale Systems. New York, McGraw-Hill, 91-164.

Sarkar, A., \& Mohapatra, P. K. (2006). Evaluation of supplier capability and performance: A method for supply base reduction. Journal of Purchase supply Management, 12, 148-163.

Sarkis, J. (2009). A boundaries and flows perspective of green supply chain management. GPMI working Papers. No-7, October. 2009.

Sharfman, M. P., Shaft, T. M., \& Anex, R. P. (2007). The road to cooperative supply-chain environmental management: trust and uncertainty among pro-active firms. Business Strategy and the Environment, 18(1), 1-13. http://dx.doi.org/10.1002/bse.580 
Srivastava, S. K. (2007). Green supply-chain management: a state-of-the-art literature review. International Journal of Management Reviews, 9(1), 53-80. http://dx.doi.org/10.1111/j.1468-2370.2007.00202.x

Tsai, W., \& Ghoshal, S. (1998). Social Capital and Value Creation: The Role of Intrafirm Networks. Academy of Management Journal, 41, 464-476, 1998. http://dx.doi.org/10.2307/257085

United Arab Emirates and the IMF. (2012). Country Info. Retrived from http://www.imf.org/external/country/are/index.htm?pn=2

United Nations Environmental Program. (2007). Building Standards and Climate Change: Status, Challenges and Oppurtunities. ISBN: 978-92-807-2795-1.

Vachon, S., \& Klassen, R. D. (2008). Environmental management andmanufacturing performance: The roleofcollaboration in the supply chain. Int. J. Prod. Econ. 111, 299-315. http://dx.doi.org/10.1016/j.ijpe.2006.11.030

Verghese, K., \& Lewis, H. (2007). Environmental innovation in industrial packaging: a supply chain approach. International Journal of Production Research, 45(18-19), 43-81. http://dx.doi.org/10.1080/00207540701450211

Vimal, K. E., Prasanta, K. D., \& Ravi, S. (2011). Enhanced Renewable Energy Adoption for Sustainable Development in India: Interpretive Structural Modeling Approach. World Renewable Energy Congress Sweden, 8-13 May, 2011, Linköping, Sweden. ISBN 978-91-7393-070-3. http://dx.doi.org/10.1016/j.jclepro.2008.04.014

Walker, H., \& Preuss, L. (2008). Fostering sustainability through sourcing from small businesses: public sector perspectives. Journal of Cleaner Production, 16(15), 1600-9.

Warfield, J. W. (1974). Developing interconnected matrices in structural modeling. IEEE Transcript on Systems, Men and Cybernetics, 4(1), 51-81.

World Bank. (2008). Country report of UAE. Retrieved from http://data.worldbank.org/country/united-arab-emirates\#cp_cc

Wycherley, I. (1999). Greening supply chains: the case of theBody Shop International. Business Strategy and the Environment,
8(2), http://dx.doi.org/10.1002/(SICI)1099-0836(199903/04)8:2<120::AID-BSE188>3.0.CO;2-X

Yu L., C. (2007). Adoption of green supply in Taiwan logistic industry. Journal of Management Study, 90-98.

Yu L., C., \& Hui H, Y. (2008). An empirical study on logistics services provider, intention to adopt green innovations. Journal of Technology, Management and Innovation, 3(1), 17-26.

Zhu, Q., \& Sarkis, J. (2007). The Moderating Effects of Institutional Pressures on Emergent Green Supply Chain Practices and Performance. International Journal of Production Research, 45(18-19), 4333-4355. http://dx.doi.org/10.1080/00207540701440345 